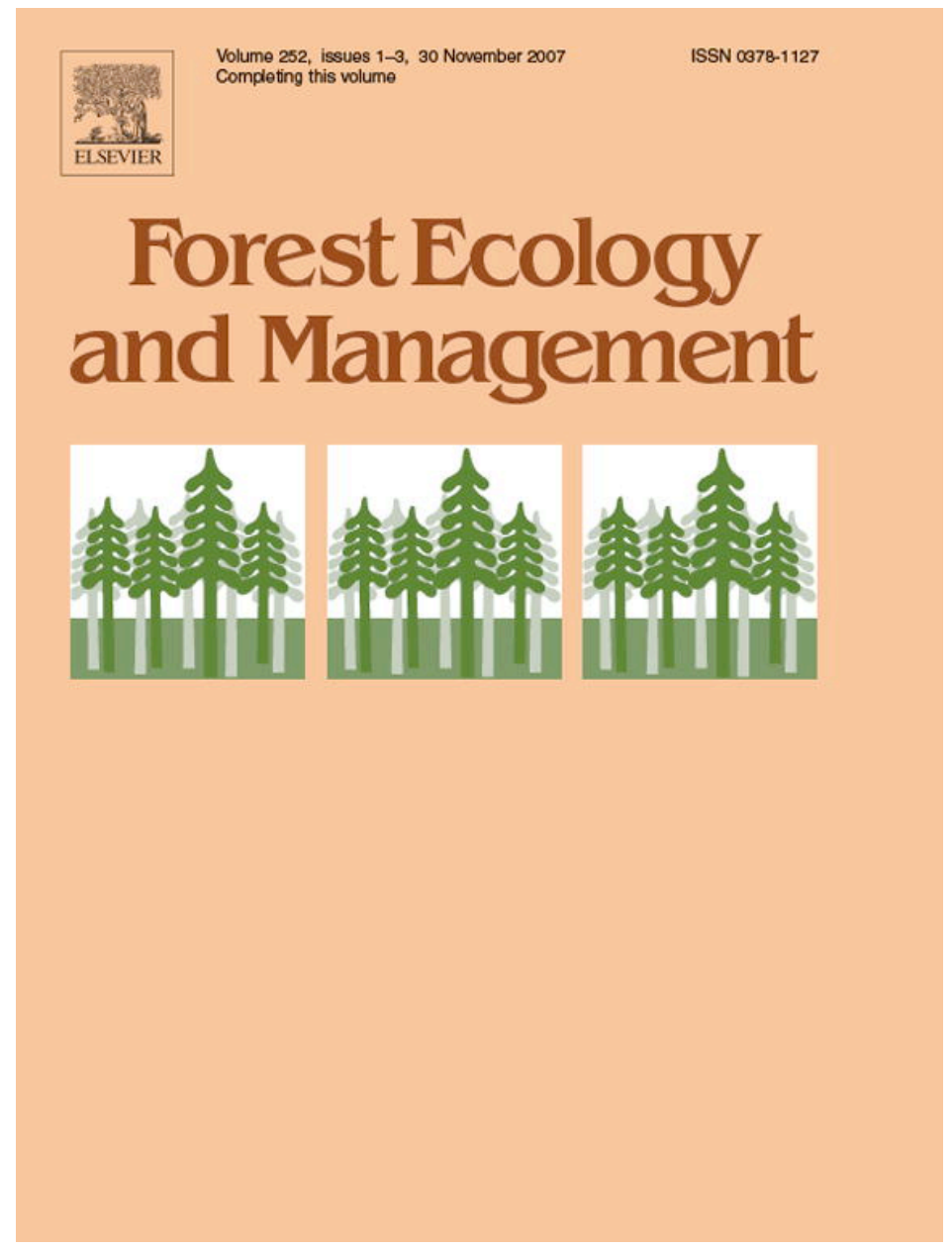

This article was published in an Elsevier journal. The attached copy

is furnished to the author for non-commercial research and education use, including for instruction at the author's institution, sharing with colleagues and providing to institution administration.

Other uses, including reproduction and distribution, or selling or licensing copies, or posting to personal, institutional or third party websites are prohibited.

In most cases authors are permitted to post their version of the article (e.g. in Word or Tex form) to their personal website or institutional repository. Authors requiring further information regarding Elsevier's archiving and manuscript policies are encouraged to visit: 


\title{
Effects of initial planting density on branch development in 4-year-old plantation grown Eucalyptus pilularis and Eucalyptus cloeziana trees
}

\author{
Philip J. Alcorn ${ }^{\mathrm{a}, \mathrm{b}, *}$, Patrick Pyttel ${ }^{\mathrm{c}}$, Jürgen Bauhus ${ }^{\mathrm{b}, \mathrm{c}}$, R. Geoff B. Smith ${ }^{\mathrm{d}}$, \\ Dane Thomas ${ }^{\mathrm{d}}$, Ryde James ${ }^{\mathrm{b}}$, Adrienne Nicotra ${ }^{\mathrm{a}}$ \\ ${ }^{a}$ School of Botany and Zoology, The Australian National University, Canberra, ACT 0200, Australia \\ ${ }^{\mathrm{b}}$ Fenner School of Environment and Society, The Australian National University, Canberra, ACT 0200, Australia \\ ${ }^{\mathrm{c}}$ Institute of Silviculture, Freiburg University, D-79085 Freiburg, Germany \\ ${ }^{\mathrm{d}}$ Forests NSW, PO Box J19, Coffs Harbour, NSW 2450, Australia
}

Received 9 February 2007; received in revised form 23 May 2007; accepted 11 June 2007

\begin{abstract}
The effect of planting density on branch development was examined in 4-year-old Eucalyptus pilularis Sm. and Eucalyptus cloeziana F. Muell. plantations located near the coast of north-eastern NSW. Branch diameter, angle and status (live or dead) were measured along the entire stem of trees established at 1250, 1667 and 3333 stems per hectare (sph). Measurements of tree height and stem diameter at breast height over bark (DBH) were also recorded. Results showed that with an increase in initial planting density from 1250 to $1667 \mathrm{sph}$, branch size decreased, branch mortality on the lower stem increased, branch angle became more acute and DBH decreased in trees of both E. pilularis and E. cloeziana. A further increase in initial planting density from 1667 to 3333 sph did not significantly reduce branch size or branch angle but did result in increased branch mortality and decreased DBH in both species. These results suggest that increasing initial planting density from 1250 to 1667 sph will improve early branch control. However, there is no advantage in establishing trees at $3333 \mathrm{sph}$ rather than $1667 \mathrm{sph}$ to reduce branch size or increase branch mortality in either species. Clearwood production on the lower stem in all stocking treatments of both species was negligible at age 4 .
\end{abstract}

(C) 2007 Elsevier B.V. All rights reserved.

Keywords: Eucalyptus pilularis; Eucalyptus cloeziana; Stocking; Density; Branches; Plantation; Tree competition; Tree spacing

\section{Introduction}

Australia has seen a dramatic increase in new plantations established over the past decade (National Forest Inventory, 2003, 2005). Most of this expansion has consisted of plantation eucalypts grown for pulpwood, however, a smaller but not insignificant area of solid wood eucalypt plantings have been established (Montagu et al., 2003). The objective of these solid wood plantings is to produce high-value logs for veneer, poles and sawn timber (Gerrand et al., 1997; Keenan et al., 1998; Bruskin, 1999; Dickinson et al., 2000) to augment or replace declining supplies of native forest logs (Faunt, 1998; Neilsen

\footnotetext{
* Corresponding author at: Nicotra Laboratory, School of Botany and Zoology, The Australian National University, Canberra, ACT 0200, Australia. Tel.: +61 26125 2671; fax: +6126125 5573 .

E-mail addresses: philip.alcorn@anu.edu.au, philip.alcorn@environment.gov.au (P.J. Alcorn).
}

and Pinkard, 2000; Nikles et al., 2000) and/or supply new and existing export markets (Keenan et al., 1998; Bruskin, 1999).

In the sub-tropical regions of the north-eastern NSW, the establishment of eucalypt plantations for solid wood production has preceded detailed knowledge of how to manipulate the stands to ensure that the wood produced is of the highest quality. Furthermore, a dramatic shift in management from native forests to shorter-rotation plantation monocultures for solid wood production requires an improved understanding of the effects of silvicultural treatment if a viable plantation program is to be established (Stanton, 1992). Here we examine the effects of stand density treatments on early branch development in two commercially important sub-tropical eucalypt plantation species.

Branch development is critical to both quantity and quality of timber produced from plantations (Clark and Saucier, 1989; Barbour and Kellogg, 1990; Mäkinen and Colin, 1999). The size and vitality status (live or dead) of branches along the stem 
and the natural branch shedding habits of the species influence the development and persistence of knots and knot-related defects (such as kino veins and decay) (Fisher, 1978; Borough and Humphreys, 1996), which are the major cause of timber degrade in solid wood eucalypt plantations (Waugh, 1996; Yang and Waugh, 1996; Leggate et al., 1998; Muneri et al., 1998; Washusen et al., 2000). Minimising or eliminating knots is essential for the production of high quality timber.

Large branches are thought to cause problems for the occlusion processes associated with branch senescence as they may not develop or retain effective brittle zones at the branchstem interface (Jacobs, 1955). Consequently it has been recommended that silvicultural practices aim to restrict branch diameter to a maximum of $25 \mathrm{~mm}$ (Jacobs, 1955; Glass, 1985; Schönau and Coetzee, 1989). Furthermore, acute angled branches $\left(<30^{\circ}\right.$ at stem $)$ can also delay branch ejection processes and the incidence of acute branch angle should be reduced using silvicultural practices where possible (Jacobs, 1955).

Establishing stands at higher initial planting densities may restrict branch development and potentially reduce the time for natural branch shedding. Increasing initial stockings have been shown to reduce maximum (Kearney, 1999; Neilsen and Gerrand, 1999; Garber and Maguire, 2005) and average branch size (Malimbwi et al., 1992; Pinkard and Neilsen, 2003) and cause an earlier rise of the green crown above the ground relative to stands established at lower planting densities across a broad range of species and sites (Bramble et al., 1949; Wardle, 1967; Opie et al., 1984; Neilsen and Gerrand, 1999; Baldwin et al., 2000). The combined effects of smaller branch sizes and earlier mortality can induce earlier branch shedding, faster occlusion and potentially earlier production of knot-free timber in sub-tropical plantation eucalypt species (Smith et al., 2006). At low stocking densities the concern is the possibility of live branches persisting on the lower stem and delaying or reducing high quality timber production on the most valuable stem section (Plumptre, 1979; Evans, 1982).

High stocking densities may be unfavourable if branch angles become more acute or individual tree size is severely reduced. In dense stands acute branch angle may be associated with the combined effects of reduced wood and foliage mass, reduced branch size (James, 2001a; Medhurst and Beadle, 2001) and greater competition for light (Henskens et al., 2001; Comeau et al., 2006). Furthermore, the increased competition for environmental resources (light, water and nutrients) with increased stocking density can reduce average stem diameter within the stand (e.g. Bramble et al., 1949; van Laar and Bredenkamp, 1979; Schönau and Coetzee, 1989; Niemistö, 1995; Kearney, 1999; Neilsen and Gerrand, 1999). While the restriction of knots and knot-related defects to a small central knotty core may be desirable, associated reduction in growth rate and stem size will increase the time required to reach final crop tree size. Higher initial stand density will also incur a higher establishment cost for seedlings and fertiliser treatments, although this may be offset by earlier competitive control of the site and reduced weed control costs. Increased rotation length and increased establishment costs will both reduce the net present value (profitability) of the plantation.
For Eucalyptus pilularis Sm. and Eucalyptus cloeziana F. Muell. plantations on the north coast of NSW, natural branch shedding processes are used to control early branch development. Under current planting prescriptions aiming to establish 1000-1250 stems per hectare (sph) (Bruskin, 1999), it has been observed that large branches ( $>25 \mathrm{~mm}$ diameter at the base) can develop before canopy closure. Such branches do not become suppressed within the lower stem ( $\leq 5.5 \mathrm{~m}$ stem height $)$ before stem size is greater than one third of the final target diameter. Planting at higher initial stockings and delaying thinning until the live crown base rises above ground to a commercial log length is an option to restrict early branch size development in these plantations (Smith et al., 2006).

The objectives of this study were to understand the effectiveness of stand density in restricting early branch development in two commercially important fast-growing subtropical eucalypt plantation species. Here we tested the hypotheses that higher initial stocking in young E. pilularis and E. cloeziana stands will lead to (1) smaller branch diameters; (2) greater branch mortality on the lower stem; (3) a reduction in branch angle; (4) a smaller stem diameter; when compared to lower initial stocking. The results of this study will provide the basis for assessing biological factors influencing the optimal spacing for each species.

\section{Methods}

\subsection{Experimental site}

Southgate is an experimental plantation located near Nana Glen in north-eastern New South Wales $\left(30^{\circ} 1^{\prime} \mathrm{S}, 153^{\circ} 8^{\prime} \mathrm{E}\right)$. The well-drained ex-pasture site contains gently sloping $\left(<4^{\circ}\right)$, deep (1-1.5 m), brown and yellow earths soils (Milford, 1999) derived from Late Carboniferous siltstone, mudstone and conglomerate (Gilligan et al., 1992). The site is approximately $165 \mathrm{~m}$ above sea level and receives moderately high rainfall (mean annual rainfall $1437 \mathrm{~mm}, 1920-2004$ ), distributed seasonally with a distinct winter minimum and summer/ autumn maximum (interpolated data from modeled climate surfaces NRM, 2007). Average daily minimum and maximum temperatures range between 13.5 and $23.6^{\circ} \mathrm{C}$ (1957-2004), however, low minimum temperatures are confined to winter months (interpolated data from modeled climate surfaces NRM, 2007). Original site vegetation consisted of a tall open mixed hardwood forest including E. pilularis, Eucalyptus intermedia R.T. Baker and Eucalyptus microcorys F. Muell. The site was cleared early in the 20th century and subsequently converted to improved pasture for grazing.

To prepare the Southgate site for plantation establishment, the soil was ripped in a north-south direction in September 2000 to a depth of $0.7 \mathrm{~m}$ and mounded to obtain $4 \mathrm{~m}$ wide row spacings, necessary for machinery access. A second cultivation was completed in planting lines one month later to increase soil tilth for planting. Herbicides (glyphosate $41 \mathrm{ha}^{-1}$, simazine $2.5 \mathrm{~kg} \mathrm{ha}^{-1}$ and metolachlor $1.51 \mathrm{ha}^{-1}$ ) were applied to the mounds one month prior to planting in December 2000. Twenty-one monospecific plots $(30 \mathrm{~m} \times 30 \mathrm{~m})$ of Eucalyptus 
Table 1

Spacing and rectangularity characteristics for $30 \times 30 \mathrm{~m}$ plots of E. pilularis and E. cloeziana at the Southgate experimental site

\begin{tabular}{llll}
\hline $\begin{array}{l}\text { Stocking } \\
(\mathrm{sph})\end{array}$ & $\begin{array}{l}\text { Tree space } \\
\left(\mathrm{m}^{2}\right)\end{array}$ & $\begin{array}{l}\text { Spacing } \\
(\text { row } \times \text { tree })(\mathrm{m})\end{array}$ & Rectangularity \\
\hline 1250 & 8 & $4 \times 2$ & 2 \\
1667 & 6 & $4 \times 1.5$ & 2.7 \\
3333 & 3 & $4 \times 1.3$ & 3.1 \\
\hline
\end{tabular}

pilularis Sm. (Whian Whian State Forest seedlot) and 21 monospecific plots of E. cloeziana F. Muell. (Pomona State Park and Mebbin State Forest plantation seedlots mixed) were established within surrounding monoculture plantations. Each plot contained an $8 \mathrm{~m}$ wide buffer around the perimeter. Nine plots of each species were established with stockings of 1250 and 1667 trees $^{-1}$ and four plots of each species were established with 3333 trees ha $^{-1}$ (Table 1). Stocking treatments were randomly assigned to plots. Seedlings were fertilised with 9 and $10 \mathrm{~g}$ of elemental nitrogen and phosphorus respectively in the form of diammonium phosphate (DAP) fertiliser at the time of planting. Post-planting weed control involved applications of haloxyfop $\left(0.51 \mathrm{ha}^{-1}\right)$ and clopyralid $\left(0.81 \mathrm{ha}^{-1}\right)$ to planted mounds one and four months after planting.

\subsection{Measurement}

Measurements were made on 10 four-year-old trees of each species and stocking treatment between 6/12/04 and 5/01/05. Dominant and co-dominant trees were selected from three plots of the same stocking that contained trees of uniform height and diameter at breast height. All sample trees had reached canopy closure and were completely surrounded by healthy neighbouring trees in all directions. Sample trees were chosen to represent the cohort that would be promoted to become the final crop trees (Table 2). The initial planting density was maintained in all plots until the time of measurement.

Sample trees in the 1667 and 3333 sph treatments were felled at ground level, while trees in the $1250 \mathrm{sph}$ treatment were measured in situ using an elevated working platform (to allow for future measurements). Before felling, the diameter at breast height over bark (DBH) was measured and marked on the selected stems. The crown radius of each tree was measured in four directions (within and across the row).

Table 2

Criteria used for final crop selection in E. pilularis and E. cloeziana stands at Southgate experimental site

\begin{tabular}{ll}
\hline Criterion & Details \\
\hline Canopy dominance & $\begin{array}{l}\text { Dominant or co-dominant in the stand } \\
\text { Health and vigour }\end{array}$ \\
$\begin{array}{l}\text { Free of significant insect attack and disease. } \\
\text { Healthy crown with a capacity for future growth } \\
\text { Lean less than } 12.5 \mathrm{~cm} \text { from the base of the tree } \\
\text { at breast height. Butt sweep deviation no more } \\
\text { than } 8 \mathrm{~cm} \text { in the first } 3 \mathrm{~m} \text { of stem } \\
\text { Absence of ramicorns (branches with diameters } \\
\text { greater than } 1 / 3 \text { stem diameter at stem junction) } \\
\text { Must have a single leader, free of broken tops } \\
\text { Stem defects }\end{array}$ & $\begin{array}{l}\text { and wood damage } \\
\end{array}$ \\
\hline
\end{tabular}

Trees were measured for total height and height to the base of the green crown. For each sample tree, the height of the green crown base was determined by subtraction of green crown depth from the total tree height. For this purpose, green crown depth was visually defined as the distance between the top of the tree and the point of stem insertion of the lowest green branch contained within a geometrically regular crown envelope (Soares and Tomé, 2001). Limbs that were retained on the stem separate from and well below the main crown were not included.

For each branch on sample trees, the following variables were measured: the height above ground, diameter over bark (to nearest $0.5 \mathrm{~mm}$ ) $30 \mathrm{~mm}$ from the base of each branch, and angle to the stem (nearest $5^{\circ}$ ) at the point of attachment. The status of each branch (live, dead or ejected) was recorded at the time of measurement. Live branches were defined as branches having green leaves, dead branches were defined as branches having no green leaves and ejected branches were defined as remnants or wounds no longer containing a live or dead branch.

\subsection{Data analysis}

Twenty-three branch characteristics were measured and analysed in order to examine the effects of stocking on branch development on the lower $5.5 \mathrm{~m}$ stem and across different crown positions. A height of $5.5 \mathrm{~m}$ was chosen in regard to standard veneer log specifications for plywood manufacture, which include a stump height of $0.3 \mathrm{~m}$ and a plywood log length of $5.2 \mathrm{~m}$ as clearwood (James, 2001b), thereby defining a principal objective of silvicultural treatment for these species.

Using Genstat (VSN International 2004, Hemel Hempstead, Herts, UK) analysis of variance (ANOVA) and generalised linear models (GLM) were used to examine differences in branch characteristics on the lower stem ( $\leq 5.5 \mathrm{~m}$ stem height) with regard to three stocking treatments. One-way ANOVA was used to explore treatment differences for mean branch diameter, mean branch angle, number and diameter of acute angled branches $\left(<30^{\circ}\right)$, height of the lowest branch, branch numbers by vitality status (live, dead, ejected), height of the first branch $>25 \mathrm{~mm}$ diameter and frequency of branch occurrence in diameter size classes (the number of branches in individual diameter classes 0-9.9, 10-19.9,. ., 40-49.9 mm expressed as a percentage of the total number across all diameter classes) on an individual tree basis. Treatment differences for the frequency of sample trees with branches $>25 \mathrm{~mm}$ diameter was also analysed using one-way ANOVA. Where error distributions for branch count data were not normally distributed (as determined by normal quantile plot of residuals), GLM with Poisson distribution was used to examine differences between treatments.

To determine differences in branch characteristics according to elevation within crowns and stocking treatment, tree crowns were divided vertically into zones (lower, middle and upper thirds). Branch position was assigned within these zones on the basis of live branch attachment on the stem. Residual maximum likelihood (REML) variance components analysis was used to analyse differences in the mean branch size and angle with 
regard to crown position and stocking treatment. Fixed effects were stocking treatment, crown zone and the interaction of these and random effects were tree and tree by crown zone. There were insufficient dead branch data from the upper crown zone for both species and this zone was excluded from the analyses.

To determine the effects of stocking treatment on stem size and crown characteristics, one-way ANOVA was used to examine differences in tree height, $\mathrm{DBH}$, height to the base of green crown, height to the lowest green branch separate from the green crown, green crown depth, projected crown area (product of mean radii within rows by mean radii between rows by $\pi$ ) and mean crown radii within and between rows. Relationships between the DBH and the largest live branch on the stem were examined using regression analysis.

\section{Results}

\subsection{Effect of stand density on branch size}

Increasing planting density from 1250 to $1667 \mathrm{sph}$ decreased mean dead branch size (Fig. 1a and b), largest live branch size (Fig. 1g, h), the number of large (diameter $>25 \mathrm{~mm}$ ) branches and the number of trees with large (diameter $>25 \mathrm{~mm}$ ) branches (Table 3) on the lower stem ( $\leq 5.5 \mathrm{~m}$ height) in both species, E. pilularis and E. cloeziana. In E. cloeziana the stem height to the first large branch (diameter $>25 \mathrm{~mm}$ ) increased with stocking but not in $E$. pilularis (Table 3 ). The diameter of live branches (Fig. $1 \mathrm{~g}, \mathrm{~h}$ ) and diameter of the largest dead branch (Fig. 1c, d) on the lower stem were also reduced with increased planting density in E. cloeziana but not E. pilularis. In all branch characteristics analysed above, there were no significant differences between the 1667 and $3333 \mathrm{sph}$ treatments in either species.

The diameter of the largest branch on the lower stem was not related to DBH in E. pilularis but was closely related in $E$. cloeziana. For E. pilularis, the lack of a relationship suggests that large branches can develop even on small diameter trees (Fig. 2). Conversely in E. cloeziana trees, the size of the largest branch increased with increasing DBH.

The frequency of small diameter branches (diameter $<10.0 \mathrm{~mm}$ ) on the lower stem increased and the frequency of larger diameter branches (10-19.9, 20-29.9 and 30$39.9 \mathrm{~mm}$ ) decreased with increased planting density from 1250 to $1667 \mathrm{sph}$, in both species (Fig. 3). Again no differences were found between the two highest planting densities across all diameter classes in either species.

Analysis of branch size within the green crown indicated reductions in live branch size with higher crown position and with an increase in planting density from 1250 to $1667 \mathrm{sph}$, in both species, but these effects were not found for dead branch size (Fig. 4). The effects were most pronounced in the lower (zone 1) and mid crown (zone 2) positions. There were no significant differences in live branch size between the two highest planting densities of 1667 and $3333 \mathrm{sph}$ in either species. (a) E. pilularis

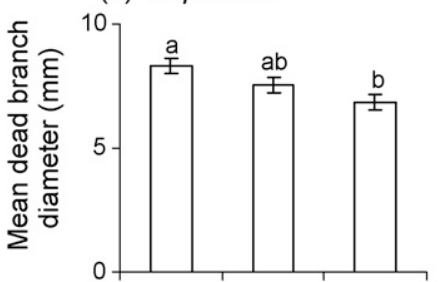

(c) E. pilularis
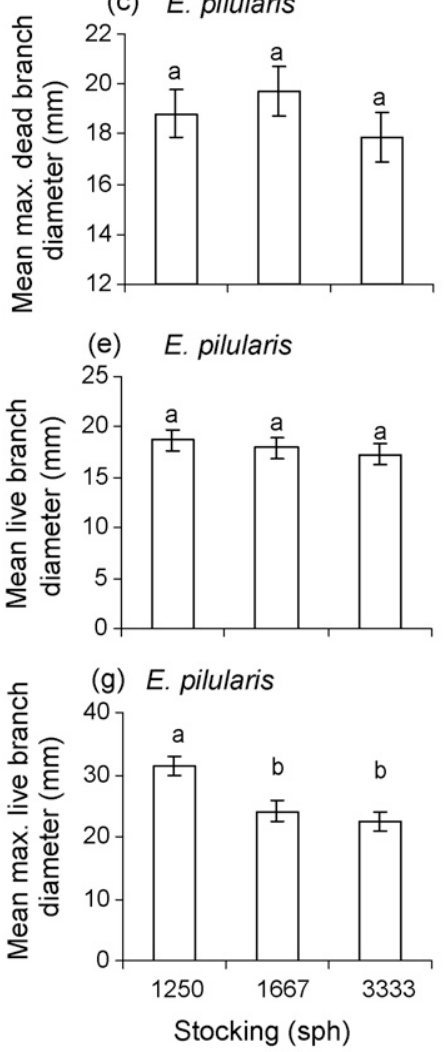

(b) E. cloeziana

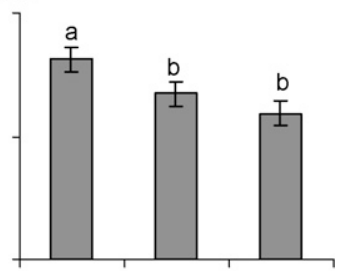

(d) E. cloeziana

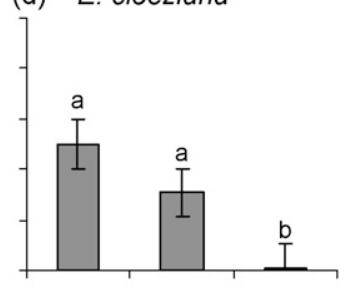

(f) E. cloeziana

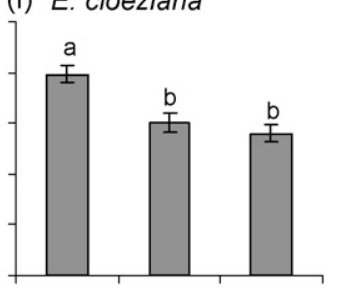

(h) E. cloeziana

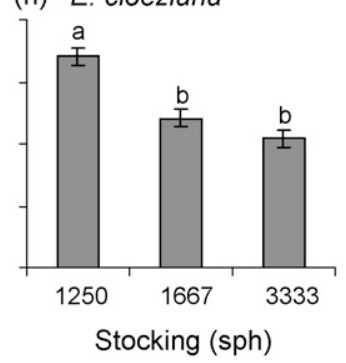

Fig. 1. Branch size characteristics on the lower $5.5 \mathrm{~m}$ stem in E. pilularis and E. cloeziana trees grown at 1250, 1667 and 3333 stems per hectare (sph). Error bars are standard errors of mean. Columns sharing the same letters are not signficantly different at the 0.05 significance level.

Analysis of crown radii indicated significant reductions in branch length within the row with increasing stocking in both species but not across rows. Mean crown radii within rows was reduced with increased stocking in both species while mean crown radii across rows was not different among stocking treatments in E. pilularis or between the 1250 and $1667 \mathrm{sph}$ stocking and the 1667 and 3333 sph stocking in E. cloeziana (Table 4).

\subsection{Effect of stand density on branch mortality}

The height of the base of the green crown above the ground increased in both species and crown depth decreased with an increase in planting density in both species (Table 4). There was also an increase in the height of the lowest green branch separate from the crown in E. pilularis but not in E. cloeziana, with increased planting density. The reduction in the number of live branches on the lower stem ( $\leq 5.5 \mathrm{~m}$ height) with increased 
Table 3

Branch characteristics on the lower $5.5 \mathrm{~m}$ of the stem in E. pilularis and E. cloeziana grown at three stocking levels

\begin{tabular}{|c|c|c|c|}
\hline & \multicolumn{3}{|l|}{ Stocking (sph) } \\
\hline & 1250 & 1667 & 3333 \\
\hline \multicolumn{4}{|l|}{ E. pilularis } \\
\hline No. branches $>25 \mathrm{~mm}$ in diameter/stem & $2.1(0.3)^{\mathrm{a}} \mathrm{a}^{\mathrm{b}}$ & $0.7(0.4) \mathrm{b}$ & $0.5(0.3) \mathrm{b}$ \\
\hline No. trees branches $>25 \mathrm{~mm}$ diameter & $9(1) \mathrm{a}$ & $4(1) b$ & $4(1) b$ \\
\hline Height 1 st branch $>25 \mathrm{~mm}(\mathrm{~m})$ & $3.2(0.5) \mathrm{a}$ & $4.3(0.5) \mathrm{a}$ & $4.0(0.5) \mathrm{a}$ \\
\hline Live branch angle $\left({ }^{\circ}\right)$ & $41(2) \mathrm{a}$ & $35(2) b$ & $35(2) b$ \\
\hline Dead branch angle $\left(^{\circ}\right)$ & $66(2) \mathrm{a}$ & $65(2) \mathrm{a}$ & $64(2) a$ \\
\hline No. acute $\left(<30^{\circ}\right.$ to stem $)$ angled branches/stem & $3(1) \mathrm{a}$ & $3(1) \mathrm{a}$ & $4(1) \mathrm{a}$ \\
\hline Diameter of acute $\left(<30^{\circ}\right.$ to stem $)$ angled branches $(\mathrm{mm})$ & 18 (1) a & $14(1) b$ & $14(1) b$ \\
\hline No. live branches & $14(2) \mathrm{a}$ & $6(2) b$ & $6(2) b$ \\
\hline No. dead branches & $40(3) \mathrm{a}$ & 48 (3) a & $42(3) \mathrm{a}$ \\
\hline No. branch holes observed & 19 (2) a & $10(2) \mathrm{a}$ & $11(2) b$ \\
\hline No. live + dead + ejected branches & $73(2) \mathrm{a}$ & $64(2) b$ & $59(2) b$ \\
\hline Height to lowest branch (m) & $0.07(0.02) \mathrm{a}$ & $0.13(0.02) \mathrm{a}$ & $0.12(0.02) \mathrm{a}$ \\
\hline \multicolumn{4}{|l|}{ E. cloeziana } \\
\hline No. branches $>25 \mathrm{~mm}$ in diameter/stem & $4.3(0.7) \mathrm{a}$ & $0.4(0.7) \mathrm{b}$ & $0.1(0.7) b$ \\
\hline No. trees branches $>25 \mathrm{~mm}$ diameter & $9(2) \mathrm{a}$ & $3(2) b$ & $1(2) b$ \\
\hline Height first branch $>25 \mathrm{~mm}(\mathrm{~m})$ & $2.7(0.4) \mathrm{a}$ & $3.2(0.4) \mathrm{a}$ & $5.2(0.4) b$ \\
\hline Live branch angle $\left({ }^{\circ}\right)$ & 49 (1) a & $42(1) b$ & $37(1) \mathrm{c}$ \\
\hline Dead branch angle $\left(^{\circ}\right)$ & 77 (2) a & $65(2) b$ & $61(2) b$ \\
\hline No. acute $\left(<30^{\circ}\right.$ to stem $)$ angled branches/stem & $2(1) \mathrm{a}$ & $4(1) \mathrm{a}$ & $6(1) b$ \\
\hline Diameter of acute $\left(<30^{\circ}\right.$ to stem $)$ angled branches $(\mathrm{mm})$ & $22(1) \mathrm{a}$ & $13(1) \mathrm{b}$ & $12(1) b$ \\
\hline No. live branches & $20(2) \mathrm{a}$ & $16(2) \mathrm{a}$ & $16(2) \mathrm{a}$ \\
\hline No. dead branches & $40(2) \mathrm{a}$ & $38(2) \mathrm{a}$ & $35(2) \mathrm{a}$ \\
\hline No. branch holes observed & $19(2) \mathrm{a}$ & $8(2) b$ & $7(2) b$ \\
\hline No. live + dead + ejected branches & 79 (3) a & $62(3) b$ & $58(3) \mathrm{b}$ \\
\hline Height to lowest branch (m) & $0.07(0.02) \mathrm{a}$ & $0.09(0.02) \mathrm{a}$ & $0.19(0.02) \mathrm{b}$ \\
\hline
\end{tabular}

a Standard error of mean shown in parentheses.

b Different letters indicate a significant difference between stocking treatment within a species at the 0.05 significance level.

planting density suggests greater branch mortality and/or reduced frequency of branch formation (Table 3). While the numbers of dead branches on the lower stem were not affected by planting density and the observed number of ejected branches decreased with increasing planting density in both species. It is probable that complete occlusion of branches was more effective at higher stem densities and that branches were no longer evident on the stem either as a branch or an ejected branch. The reduction in projected crown area (PCA) with increased planting density shows further evidence of greater branch suppression at higher planting densities (Table 4).

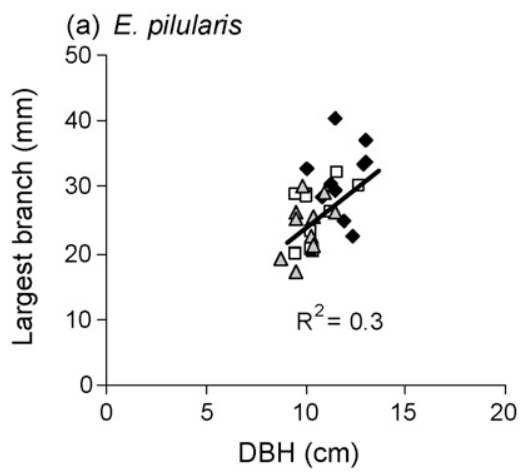

The fact that the height of the base of the green crown was greater than the height to the lowest green branch indicates that total branch suppression below the green crown was incomplete in both species. The results also indicate that in all treatments live branches had not been completely suppressed in the target clearwood height of $5.5 \mathrm{~m}$ at age 4 years, although this was being approached for the two highest planting densities in $E$. pilularis.

Clearwood production on the lower stem was limited in both species at age 4 . The height to the lowest branch was less than $0.2 \mathrm{~m}$ in all treatments for both species, despite an increase in

\section{(b) E. cloeziana}

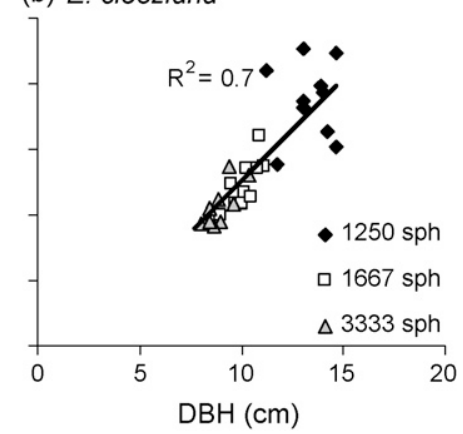

Fig. 2. Relationship between largest branch diameter (live or dead) and stem diameter at breast height over bark (DBH) for trees grown at 1250,1667 and 3333 stems per hectare (sph) for (a) E. pilularis and (b) E. cloeziana. 

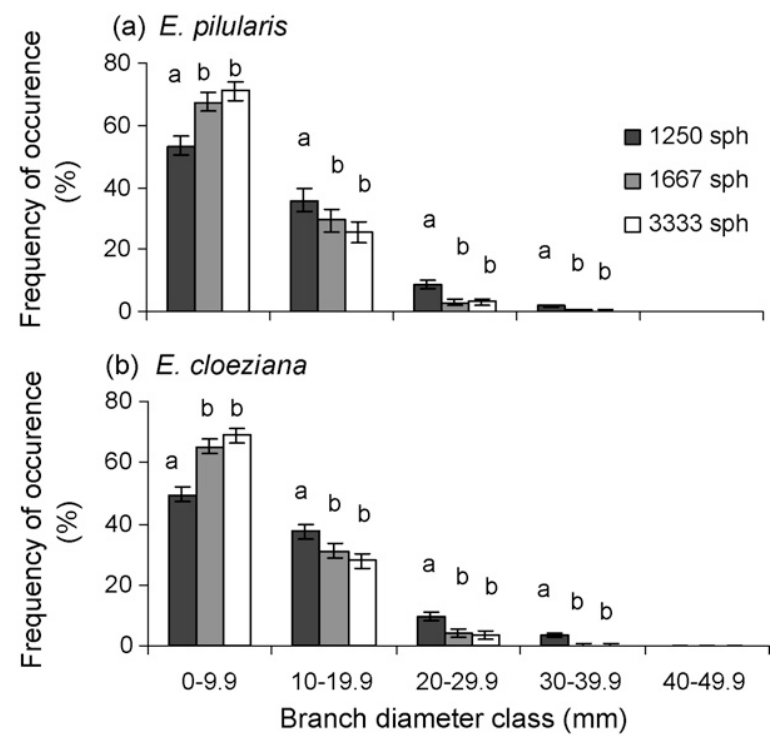

Fig. 3. Effect of stocking density on frequency distribution of branch diameter in (a) E. pilularis and (b) E. cloeziana grown at 1250, 1667 and 3333 stems per hectare (sph). Error bars are standard errors of mean. Columns sharing the same letters are not signficantly different at the 0.05 significance level.

lowest branch height above the ground in E. cloeziana (Table 3).

\subsection{Effect of stand density on branch angle}

The angle of live branches on the lower stem $(\leq 5.5 \mathrm{~m}$ height) became more acute with increased planting density in both species while dead branch angle was reduced in $E$. cloeziana but not in E. pilularis (Table 4). The number of very acute angled $\left(<30^{\circ}\right.$ to stem) branches on the lower stem was significantly increased with increased planting density for $E$. cloeziana but not for E. pilularis (Table 4). The mean basal diameter of very acutely angled branches on the lower stem decreased with increased planting density from 1250 to $1667 \mathrm{sph}$ in both species (Table 3).
Further analysis of live and dead branch angle within the green crown indicated significant changes in branch size with crown position and planting density in both species (Fig. 4). Across all crown positions, the angle of both live and dead branches generally declined with increasing stocking. However, there were no significant differences between the two higher planting densities in either species.

\subsection{Effect of density on stem size}

Stem density affected stem size in both species. Diameter at breast height over bark (DBH) declined with increasing planting densities in both species (Fig. 5). Tree height was less clearly affected by planting densities within the range of treatments for E. pilularis but declined with planting density in E. cloeziana (Fig. 5).

\section{Discussion}

The results of this study support our hypotheses that branch and stem size decrease, while branch mortality increases and branch angle become more acute with increases in initial planting density in E. pilularis and E. cloeziana plantations. With an increase in initial planting density from 1250 to $1667 \mathrm{sph}$ hectare all four such responses were substantiated. Further increase in initial planting density from 1667 to 3333 sph did not lead to further significant reductions in either branch size or branch angle but did further increase branch mortality and decrease stem size.

\subsection{Stand density effects on branch size}

Reductions in branch basal diameter with an increase in initial planting density from 1250 to $1667 \mathrm{sph}$ in both $E$. pilularis and E. cloeziana confirm the results of other studies in plantation-grown eucalypts. Studies in Eucalyptus nitens (Deane and Maiden) Maiden (Neilsen and Gerrand, 1999; Pinkard and Neilsen, 2003), Eucalyptus globulus Labill.

Table 4

Crown characteristics for trees of E. pilularis and E. cloeziana trees grown at 1250, 1667 and 3333 stems per hectare (sph)

\begin{tabular}{|c|c|c|c|}
\hline & \multicolumn{3}{|l|}{ Stocking (sph) } \\
\hline & 1250 & 1667 & 3333 \\
\hline \multicolumn{4}{|l|}{ E. pilularis } \\
\hline Height to base of green crown (m) & $2.4(0.3)^{\mathrm{a}} \mathrm{a}^{\mathrm{b}}$ & $4.3(0.3) \mathrm{b}$ & $4.5(0.3) b$ \\
\hline Height to lowest green branch (m) & $2.2(0.4) \mathrm{a}$ & $3.2(0.4) \mathrm{b}$ & $3.3(0.4) b$ \\
\hline Crown depth $(\mathrm{m})$ & $8.4(0.3) \mathrm{a}$ & $7.4(0.3) \mathrm{b}$ & $6.8(0.3) \mathrm{b}$ \\
\hline $\operatorname{PCA}^{\mathrm{c}}\left(\mathrm{m}^{2}\right)$ & $11.8(0.4) \mathrm{a}$ & $11.4(0.4) \mathrm{a}$ & $9.4(0.4) \mathrm{b}$ \\
\hline Number of trees & 10 & 10 & 10 \\
\hline \multicolumn{4}{|l|}{ E. cloeziana } \\
\hline Height to base of green crown (m) & $1.4(0.2) \mathrm{a}$ & $2.7(0.2) \mathrm{b}$ & $3.0(0.2) \mathrm{b}$ \\
\hline Height to lowest green branch (m) & $1.3(0.3) \mathrm{a}$ & $1.1(0.3) \mathrm{a}$ & $1.4(0.3) \mathrm{a}$ \\
\hline Crown depth $(\mathrm{m})$ & $10.7(0.3) \mathrm{a}$ & $9.1(0.3) \mathrm{b}$ & $7.8(0.3) \mathrm{c}$ \\
\hline $\mathrm{PCA}\left(\mathrm{m}^{2}\right)$ & $13.7(0.4) \mathrm{a}$ & $12.1(0.4) b$ & $10.7(0.4) \mathrm{c}$ \\
\hline Number of trees & 10 & 10 & 10 \\
\hline
\end{tabular}

\footnotetext{
a Standard errors of mean for each species are shown in parentheses.

b Different letters indicate a significant difference between stocking treatment within a species at the 0.05 significance level.

c PCA refers to projected crown area.
} 


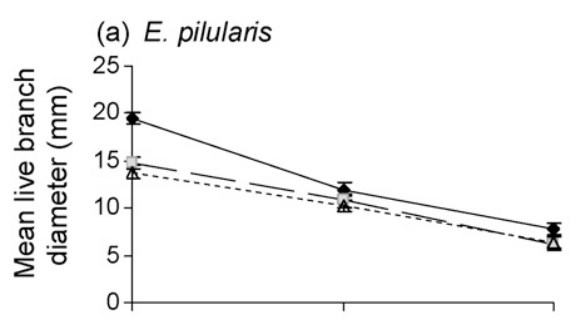

(c) E. pilularis
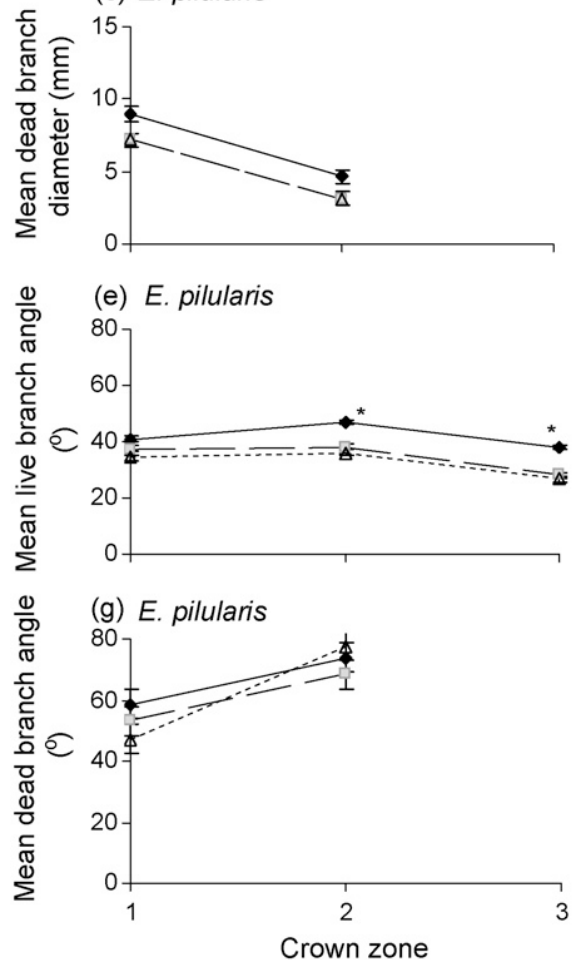

(b) E. cloeziana

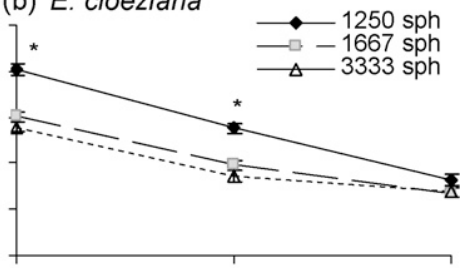

(d) E. cloeziana
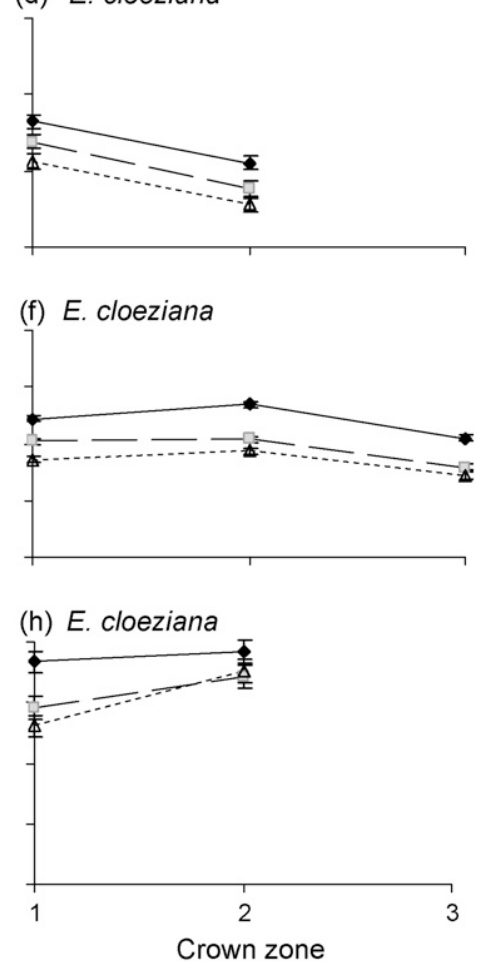

Fig. 4. Branch size and angle characteristics in the lower (1), middle (2) and upper (3) crown zone of E. pilulars and E. cloeziana trees grown at at 1250 , 1667 and 3333 stems per hectare (sph). Error bars are standard errors of mean. *A significantly different mean branch diameter from all other treatments within a crown zone, at 0.05 significance level.

(Henskens et al., 2001), Eucalyptus grandis W. Hill ex Maiden and E. pilularis (Kearney, 1999) have each reported reductions in branch size with increased stocking up to $1667 \mathrm{sph}$. It has been argued that stand density can effectively regulate branch size because this factor has relatively low broad-sense heritability (Otegbeye and Samarawira, 1992). This means that branch sizes are largely controlled by the environment, or the resources (e.g. light) available for leaf area and biomass development (Daniel et al., 1979). Given the close relationship between branch diameter and branch length (Henskens et al., 2001; Medhurst and Beadle, 2001; Pinkard and Neilsen, 2003), a reduction in available environmental resources for branch extension from 1250 to $1667 \mathrm{sph}$ was considered likely to have lead to reduction in branch diameters in this study.

The lack of reduction in branch size or branch mortality characteristics with a doubling of planting density from 1667 to 3333 sph suggests sunlight availability on the lower stem may be comparable in both treatments by age 4 years. This may have been related to the greater similarity in rectangularity values in the two higher stocked treatments than the two lower stocked treatments (Table 1). Our results showed that crown radii across the rows were not different for the 1667 and $3333 \mathrm{sph}$ treatments (Table 4). These results are consistent with a rectangularity study in 12-year-old E. saligna grown at $740 \mathrm{sph}$ where changes in branch growth were only evident at extreme rectangularity (Glass, 1985). While a recent study of planting rectangularity in 5-year-old $E$. nitens grown at stocking treatments in the range $278-2500 \mathrm{sph}$ reported no effect of rectangularity of spacing on branch attributes (Gerrand and Neilsen, 2000), the most extreme rectangularity treatments were less than those in our study.

\subsection{Stand density effects on branch mortality}

The increased rise of the green crown in E. pilularis and $E$. cloeziana and greater rise of the lowest green branch in $E$. pilularis with increased planting density from 1250 to $1667 \mathrm{sph}$ provides evidence for increased branch suppression and competition for resources (Opie et al., 1984) up to $1667 \mathrm{sph}$. Generally the rate of rise of the green crown base increases with increasing stand density in both softwoods (Beekhuis, 1965; Maguire and Hann, 1990) and hardwoods (Neilsen and 


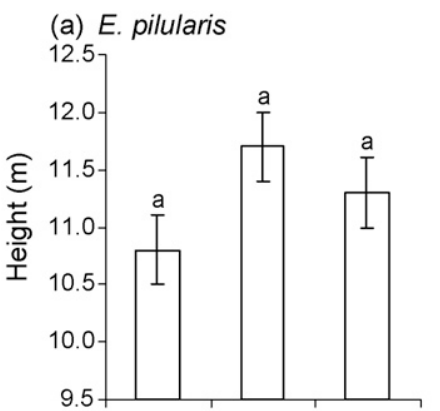

(b) E. cloeziana
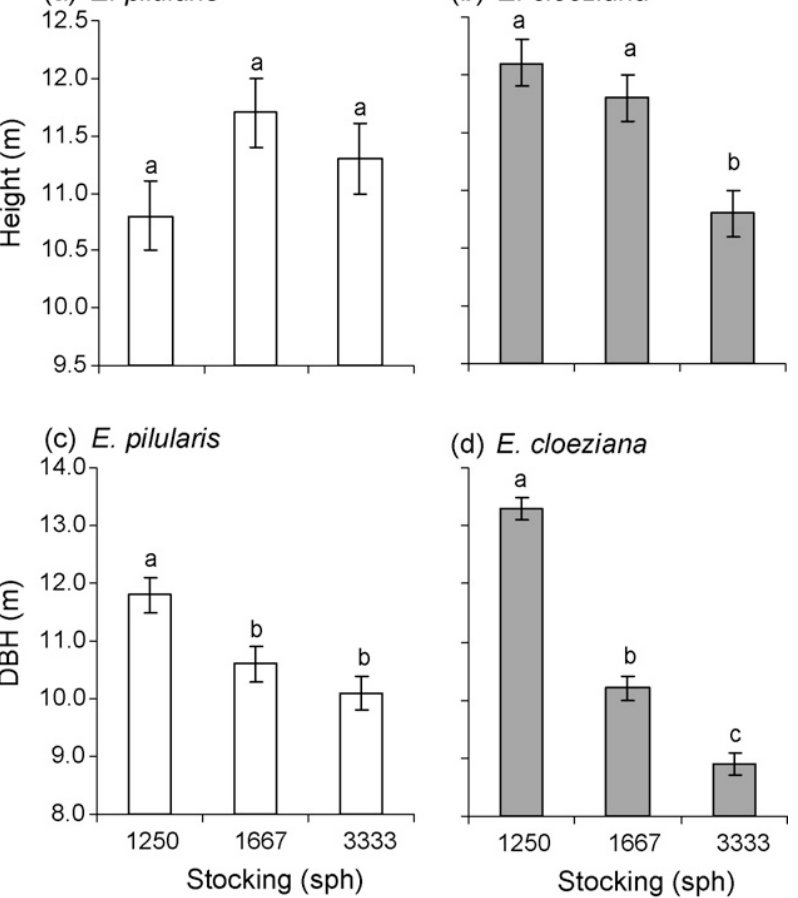

(d) E. cloeziana

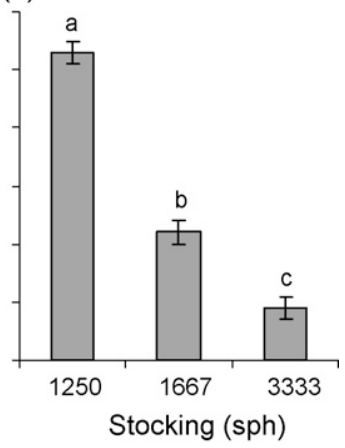

Fig. 5. Effect of stocking density on height and diameter at breast height over bark (DBH) in E. pilularis and E. cloeziana grown at 1250, 1667 and 3333 stems per hectare (sph). Error bars are standard errors of mean. Columns sharing the same letters are not signficantly different at the 0.05 significance level.

Gerrand, 1999; Klootwijk, 2001) as competition between trees for resources, particularly light, intensifies (Opie et al., 1984).

Increasing stocking above $1667 \mathrm{sph}$ had little influence on green crown height or height to the lowest green branch separate from the green crown in this study. This is consistent with Klootwijkk's (2001) finding that the rate of increase in green crown rise above the ground was greater with an increase in stand density from $838 \mathrm{sph}$ to $1667 \mathrm{sph}$ in young $E$. grandis than from 1667 to $3333 \mathrm{sph}$. The lack of difference in crown properties above $1667 \mathrm{sph}$ may have been influenced by focusing on dominant and co-dominant trees only, which appear to maintain a similar sized crown beyond $1667 \mathrm{sph}$. Examination of the entire population may produce greater differences between stocking treatments as the proportion of sub-dominant and suppressed trees are likely to show smaller crowns in response to resource limitation than co-dominant and dominant trees. However, there may be a stand density level, beyond which further increases in stocking do not affect crown dynamics (Montagu et al., 2003). This is supported by findings of Opie et al. (1984) that $70 \%$ of the maximum green crown rise was reached at $1000 \mathrm{sph}$ in E. regnans at age 11 and variable results in green crown rise occurred between 1807 and $5627 \mathrm{sph}$. It is unclear whether this is true for other species as there are few data gathered for other species with highly stocked treatments above $1667 \mathrm{sph}$ (e.g. Neilsen and Gerrand, 1999; Pinkard and Neilsen, 2003).

Suppression of lower branches appeared to be more pronounced in E. pilularis than in E. cloeziana at age 4. In $E$. pilularis there was a higher lift of the green crown and the lowest green branch than for E. cloeziana (Table 4) and a lower number of live branches on the lower stem (Table 3 ) than in $E$. cloeziana. This is consistent with the observation by Smith et al. (2006) that young plantation-grown E. cloeziana has a tendency to retain live branches. The ability for greater branch retention of E. cloeziana over E. pilularis may relate more to the species' architectural strategy for gathering light within a forest than to leaf physiology differences. Eucalyptus cloeziana showed a greater tendency for small branch bifurcation, horizontal branch twist and more horizontal leaf orientation.

Dead branch counts on the lower stem ( $\leq 5.5 \mathrm{~m}$ height $)$ were not different between planting density treatments in either species in this study. However, fewer ejected branch holes were evident at closer spacings (Table 3). The lower number of holes from ejected branches at closer spacings is likely to be the effect of branches being totally occluded at age four and no longer visible on the stem. It is unlikely to be the result of lower numbers of branches, as branch initiation is more an expression of genotype than environment (Colin et al., 1993). Recent studies have confirmed that the number of branches per unit of crown depth (Pinkard and Neilsen, 2003) or unit length of stem (Kearney, 1999) are constant across differing stocking treatments. Therefore, in this study, the apparently lower number of ejected branch holes on the stem at higher density (Table 3) must be the result of smaller branches or shorter branch stubs, since the stem growth rate (Fig. 5), and hence occlusion rate, was less than in the wider spacing.

Despite evidence of branch suppression through the death of the lower foliage and rise of the green crown, clearwood production over the entire log had not commenced in either species. The shedding of branches and the occlusion of branch stubs is necessary before clearwood is produced (Montagu et al., 2003). The presence of branches above $0.2 \mathrm{~m}$ stem height in all stocking treatments in both species (Table 3) suggests clearwood production had not commenced in either species.

\subsection{Stand density effects on branch angle}

The reduction of live branch angle to stem with increasing planting density in both species supports findings in E. globulus where increased branch angle has been found to occur at wider spacings (Henskens et al., 2001). It is suggested that the reduction in live branch angle at close spacings is an important adaptation that will maximise leaf area display for light capture and minimise self-shading (see Hollinger, 1989). The increased dead branch angle to stem in E. cloeziana at the lower planting density (Table 3) may be the effect of increased live branch angles or of older age of branches before being shed or higher radial stem growth rates, or some combination of these factors. With increasing time since mortality there is generally a lowering of the branch angle as radial stem growth pushes branches downward (Florence, 1996).

The more acute branch angles observed on trees in the 1667 and $3333 \mathrm{sph}$ treatments have the potential to increase the sectional area of knots (Henskens et al., 2001) and knot defects compared with trees growing at $1250 \mathrm{sph}$. However, the combined effects of reduced frequency of large branches and smaller mean branch diameter in trees growing at 1667 
and $3333 \mathrm{sph}$, however, suggests that aggregate knot defect may not actually increase despite more acute angled branches.

The increased frequency of branches on the lower stem with angles $<30^{\circ}$ from the stem found of E. cloeziana planted at $3333 \mathrm{sph}$ has the potential delay clearwood production. Very acute angled $\left(<30^{\circ}\right.$ from stem) branches can delay the branch shedding and stub ejection processes (Jacobs, 1955). These results contrast with Neilsen and Gerrand's (1999) study in $E$. nitens, where acute angled $\left(<30^{\circ}\right.$ from stem) branch frequency was unaffected by stocking.

\subsection{Stand density effects on stem size}

The reduction in stem diameter with increased planting density from 1250 to $1667 \mathrm{sph}$ in both E. pilularis and E. cloeziana is consistent with other spacing and density experiments in E. nitens (Neilsen and Gerrand, 1999; Pinkard and Neilsen, 2003), E. grandis (Schönau, 1974; Meskimen and Franklin, 1978; van Laar and Bredenkamp, 1979; Schönau and Coetzee, 1989; Kearney, 1999), Eucalyptus urophylla S.T. Blake, Eucalyptus pellita F. Muell., Eucalyptus camaldulensis Dehn (Bernardo et al., 1998), E. tereticornis (Chapola et al., 1995) and other broadleaf (Niemistö, 1995) and conifer species (Ware and Stahelin, 1948; Bramble et al., 1949; Malimbwi et al., 1992; Deans and Milne, 1999).

The effect of planting density on height growth was not as pronounced as the effects on diameter in this study, and is consistent with other studies (Deans and Milne, 1999; Neilsen and Gerrand, 1999). The observed reduction in height in $E$. cloeziana at the highest initial planting density, which was not found in E. pilularis, may be an effect of an extremely crowded stand (Smith et al., 1997) and/or the effect of selecting both dominant and co-dominant trees within the stand. Studies in eucalypts (Opie et al., 1984) and other broadleaf (e.g. Niemistö, 1995) and conifer species (e.g. Malimbwi et al., 1992) have found that increasing planting density may reduce mean height of all trees in the sample area but less so for the mean dominant height.

\subsection{Management implications}

As an alternative to the expensive physical removal of branches from the lower stem through pruning, it has been suggested it may be possible to use higher initial stockings at planting and delaying thinning until the crown base has risen sufficiently high (Smith et al., 2006). From a branch development point of view, results here indicate that planting at a density of $1667 \mathrm{sph}$ is more desirable than $1250 \mathrm{sph}$, however, there is no gain in planting stems at $3333 \mathrm{sph}$ at the current distance of $4 \mathrm{~m}$ across planting rows which is required for machinery access. In fact, given the reduced stem size and potential to restrict height growth without further reductions in branch size in E. cloeziana, planting density above $1667 \mathrm{sph}$ would not be recommended. This concurs with Schönau's (1984) recommendation that optimum planting density for eucalypts is between 1200 and $2000 \mathrm{sph}$.
The major disadvantage with utilising the natural processes of branch senescence and shedding to produce clearwood or knot free timber is the uncertainty associated with the time required for branches to die and shed and for branch stubs to occlude on the lower stem. The retention of live or dead branches on the lower stem for long periods following branch mortality will delay clearwood production. One feature of both species studied was the tendency to retain dead branches below the green crown base in all treatments. While it is not known how long these will be retained, it has been suggested elsewhere that both E. cloeziana and $E$. pilularis do not eject dead branches as effectively as other sub-tropical eucalypt species such as E. grandis (Smith et al., 2006). In addition, the very low green crown height and height to lowest green branch in E. cloeziana suggests longer live branch retention across all spacings when compared with $E$. pilularis. Since smaller branches have been shown to occlude faster than larger branches in the species studied here (Smith et al., 2006) and elsewhere (Rapraeger, 1939; Pietilä, 1989; Mäkinen, 1999), closer spacing will be important in restricting branch size and minimising the time for dead branches to occlude. Further research is needed to understand the length of time taken for dead branches to shed and branch stubs to occlude in both species. The retention of dead branches on the lower stem increases the size (diameter) of the knotty core and has lead to adoption of live (green) branch pruning for clearwood production in E. nitens (Pinkard and Beadle, 1998). Similarly the retention of live branches in Eucalyptus saligna Sm. has prompted recommendations for early live branch pruning for clearwood production (Glass, 1985). While Smith et al. (2006) showed that there were no difference in rates of occlusion between pruned and unpruned dead branch stubs, pruning branches while they are green will overcome the uncertainty in branch mortality and time taken for shedding of dead branches. Live branch pruning directly removes branches from the stem, so there is more certainty about the time and stem size at which clearwood production commences. Furthermore, the issue of green branch retention below the main green crown has the potential for very large (and more persistent) branches developing and the occurrence of associated wood defect issues through natural branch shedding of these large branches.

Incomplete rise of the green crown can delay clearwood production. The presence of persistent live branches will delay thinning under present prescriptions, which is necessary to increase growth rates, until the lowest live branch is above the designated lower stem height. In this study, for both $E$. pilularis and E. cloeziana, the rise of the green crown was incomplete, with trees of both species retaining individual live branches below the basal height of the green crown. Thinning the stand before the death of persistent live branches will maintain these on remaining stems and lead to the development of larger branches (Medhurst and Beadle, 2001) which only exacerbate subsequent defect problems.

\section{Conclusions}

Planting E. pilularis and E. cloeziana trees at $1667 \mathrm{sph}$ rather than $1250 \mathrm{sph}$ did result in reductions in branch size, 
increased frequency of smaller branches and increased branch mortality on the lower stem at age 4 years. There was also a reduction in stem diameter but not height with this increase in density. There is no advantage in planting trees at $3333 \mathrm{sph}$ rather than $1667 \mathrm{sph}$ to control branch size development or improve branch mortality in either species.

The combination of reduced stem diameter growth, smaller individual tree size and increased branch suppression by planting trees at $1667 \mathrm{sph}$ instead of $1250 \mathrm{sph}$ may lead to a smaller central knotty core in both E. pilularis and E. cloeziana stands. However, the major disadvantage with relying on natural branch shedding processes to produce clearwood on the lower stem is the length of time required for branches to die, be shed and the stubs to occlude and comparison of these time lapses was beyond the scope of the present study. If natural branch pruning is used to control branch development and produce high-value clearwood, determining optimum spacing will depend not only a more detailed analysis of biological processes but also on careful considerations of management, economic and market factors (Shepherd, 1986; Shepherd et al., 1990; Neilsen and Gerrand, 1999).

It may be more desirable to remove the high degree of uncertainty by resorting to artificial pruning to produce clearwood earlier and more rapidly on the lower stem provided effects on growth are known and accounted. The viability of pruning these species, however, will depend on the capacity to prune trees before the green crown rises in order to avoid defect problems with increased knotty core. In E. pilularis, this may be quite early and potentially difficult as this study inferred earlier rise of the green crown above the ground than for E. cloeziana at age 4 years.

\section{Acknowledgements}

The authors would like to thank Forests NSW for the use of the experimental site and financial assistance with this research. We would also like to thank Daryl Johnston and Piers Harper for assistance in the field. Philip Alcorn was supported by an Australian Postgraduate Award Industry scholarship (ARC Grant LP0348999) and CRC Forestry scholarship. We also thank two anonymous reviewers for their helpful comments.

\section{References}

Baldwin Jr., V.C., Peterson, K.D., Clark, A., Ferguson, R.B., Strub, M.R., Bower, D.R., 2000. The effects of spacing and thinning on stand and tree characteristics of 38-year-old Loblolly Pine. For. Ecol. Manage. 137, 91102.

Barbour, R.J., Kellogg, R.M., 1990. Forest management and end-product quality: a Canadian perspective. Can. J. For. Res. 20, 405-414.

Beekhuis, J., 1965. Crown depth of radiata pine in relation to stand density and height. N. Z. J. For. 10, 43-61.

Bernardo, A.L., Reis, M.G.F., Reis, G.G., Harrison, R.B., Firme, D.J., 1998 Effect of spacing on growth and biomass distribution in Eucalyptus camaldulensis, E. pellita and E. urophylla plantations in southeastern Brazil. For. Ecol. Manage. 104, 1-13.

Borough, C., Humphreys, N., 1996. Bark encased knots-surprise in store for forest growers? Aust For. Grow. Special Liftout Section No. 19 (37), 31-38.
Bramble, W.C., Cope, H.N., Chisman, H.H., 1949. Influence of spacing on growth of Red Pine in plantations. J. For. 47, 726-732.

Bruskin, S., 1999. New South Wales eucalypt plantation expansion-a silvicultural perspective. In: Ellis, R.C., Smethurst, P.J. (Eds.), Practising Forestry Today Proceedings of the 18th Biennial Conference of the Institute of Foresters of Australia. Institute of Foresters of Australia, Hobart, pp. $152-156$.

Chapola, G.B.J., Mwabumba, L., Kuyuma, O.T.B.S., 1995. Effects of initial spacing and thinning on yield and basic density of Eucalyptus tereticornis at Liwonde, Southern Malawi. J. Trop. For. Sci. 8, 1-14.

Clark, A., Saucier, J.R., 1989. Influence of initial planting density, geographic location, and species on juvenile wood formation in southern pine. For. Prod. J. 39, 42-48.

Colin, P.F., Houllier, F., Joannes, H., Haddaui, A., 1993. Modélisation du profil vertical des diamétres, angles et nombres de branches pour trois provenances d'epicea commun. Silvae Genet. 42, 206-222.

Comeau, P.G., Heineman, J., Newsome, T., 2006. Evaluation of relationships between understory light and aspen basal area in the British Columbia central interior. For. Ecol. Manage. 226, 80-87.

Daniel, T.W., Helms, J.A., Baker, F.S., 1979. Principles of Silviculture. McCraw-Hill Book Company, New York, p. 500.

Deans, J.D., Milne, R., 1999. Effects of respacing on young Sitka spruce crops Forestry 72, 47-57.

Dickinson, G.R., Leggate, W., Bristow, M., Nester, M., Lewty, M.J., 2000. Thinning and pruning to maximise yields of high value timber products from tropical and sub-tropical hardwood plantations. In: Snell, A., Vize, S (Eds.), Opportunities for the New Millennium. Conference Proceedings. Australian Forest Growers, Cairns, pp. 32-42.

Evans, J., 1982. Plantation Forestry in the Tropics. Oxford University Press, New York, p. 472

Faunt, K., 1998. Current research in eucalypt pruning in NSW. In: Dyason, R., Dyason, L., Garsden, R. (Eds.), Plantation and Regrowth Forestry: A Diversity of Opportunity. Conference Proceedings. Australian Forest Growers, Lismore, pp. 159-164.

Fisher, W.J., 1978. Spacing, branch size, branch longevity and wood quality in plantations of hoop pine at Yarraman. Technical Paper No. 12, Department of Forestry, Queensland, Brisbane, p. 17.

Florence, R.G., 1996. Ecology and Silviculture of Eucalypt Forests. CSIRO, Collingwood, p. 413.

Garber, S.M., Maguire, D.A., 2005. Vertical trends in maximum branch diameter in two mixed-species spacing trials in the central Oregon Cascades. Can. J. For. Res. 35, 295-307.

Gerrand, A.M., Neilsen, W.A., 2000. Comparing square and rectangular spacings in Eucalyptus nitens using a Scotch plaid design. For. Ecol. Manage. $129,1-6$.

Gerrand, A.M., Neilsen, W.A., Medhurst, J.L., 1997. Thinning and pruning eucalypt plantations for sawlog production in Tasmania. Tasforests 9, 1534.

Gilligan, L.B., Brownlow, J.W., Cameron, R.G., Henley, H.F., 1992. DorrigoCoffs Harbour 1:250000 Metallogenic Map SH/56-10, SH/56-11: Metallogenic Study and Mineral Deposit Data Sheet. Department of Mineral Resources, Sydney, NSW.

Glass, B.P., 1985. Some Factors Affecting Branch Control and Defect Core in Eucalyptus saligna. Forest Research Institute Bulletin No. 87. New Zealand Forest Service, Rotorua, 9.

Henskens, F.L., Battaglia, M., Cherry, M.L., Beadle, C.L., 2001. Physiological basis of spacing effects on tree growth and form in Eucalyptus globulus. Trees 15, 365-377.

Hollinger, D.Y., 1989. Canopy organization and foliage photosynthetic capacity in a broad-leaved evergreen montane forest. Funct. Ecol. 3, 53-62.

Jacobs, M.R., 1955. Growth habits of the Eucalypts. Forestry and Timber Bureau, Canberra, p. 262.

James, R., 2001a. Some silvicultural characteristics of plantation grown Flooded Gum and Black Butt on the North Coast, NSW. In: Lott, R. (Ed.), National Farm Forestry Silviculture Project Workshop. QFRI, AFFA and RIRDC, Brisbane, pp. 1-10.

James, R.N., 2001b. Defining the Product Log Grades Used in Australia: A Report for the RIRDC/Land \& Water Australia/FWPRDC Joint Venture 
Agroforestry Program. Shaping the future. Rural Industries Research and Development Corporation, Canberra, p. 30.

Kearney, D., 1999. Characterisation of branching patterns, changes caused by variations in initial stocking and implications for silviculture, for $E$. grandis and E. pilularis plantations in the North Coast region of NSW. Honours Thesis. Department of Forestry. The Australian National University, Canberra, p. 89.

Keenan, R.J., Ivory, M., Lawson, S., Lee, D., Leggate, W., Lewty, M.J., Nikles, D.G., Ryan, P., Walker, S., 1998. Hardwood Plantation Research and Development: A Strategy to Support a Hardwood Plantation Industry in Queensland. Queensland Forestry Research Institute Report 483. Department of Primary Industries Forestry, Gympie, p. 34.

Klootwijk, T., 2001. Modelling crown rise in Eucalyptus grandis (W. Hill Ex Maiden) grown on the North Coast of New South Wales. Honours Thesis. School of Resources, Environment and Society, The Australian National University, Canberra, p. 105.

Leggate, W., Palmer, G., Walduck, B., 1998. Economic aspects of eucalypt hardwood plantation forestry. In: Dyason, R., Dyason, L., Garsden, R. (Eds.), Plantation and Regrowth Forestry: A Diversity of Opportunity. Conference Proceedings. Australian Forest Growers, Lismore, pp. 229243.

Maguire, D.A., Hann, D.W., 1990. Constructing models for direct prediction of 5 -year crown recession in southwestern Oregon Douglas-fir. Can. J. For. Res. 20, 1044-1052.

Mäkinen, H., 1999. Growth, suppression, death, and self-pruning of branches of Scots pine in southern and central Finland. Can. J. For. Res. 29, 585-594.

Mäkinen, H., Colin, F., 1999. Predicting the number, death, and self-pruning of branches in Scots pine. Can. J. For. Res. 29, 1225-1236.

Malimbwi, R.E., Persson, A., Iddi, S., Chamshama, S.A.O., Mwihomeke, S.T., 1992. Effects of spacing on yield and some wood properties of Pinus patula at Rongai, northern Tanzania. For. Ecol. Manage. 53, 297-306.

Medhurst, J.L., Beadle, C.L., 2001. Crown structure and leaf area index development in thinned and unthinned Eucalyptus nitens plantations. Tree Physiol. 21, 989-999.

Meskimen, F.C., Franklin, C., 1978. Spacing Eucalyptus grandis in Southern Florida - a question of merchantable volume versus total volume. South. J. Appl. For. 2, 3-5.

Milford, H.B., 1999. Soil Landscapes of the Coffs Harbour 1: 100000 Sheet Report. Department of Land and Water Conservation, Sydney.

Montagu, K.D., Kearney, D.E., Smith, R.G.B., 2003. The biology and silviculture of pruning planted eucalypts for clear wood production - a review. For. Ecol. Manage. 179, 1-13.

Muneri, A., Leggate, W., Palmer, G., Ryan, P., 1998. The influence of age and site on wood properties of plantation-grown Eucalyptus cloeziana and the implications for utilisation. In: Managing and Growing Trees Training Conference, Proceedings. Queensland Department of Natural Resources and Mines, Brisbane, pp. 290-296.

National Forest Inventory, 2003. National Plantation Inventory Annual Update-March 2003. Bureau of Rural Sciences, Canberra, p. 8.

National Forest Inventory, 2005. National Plantation Inventory 2005 Update. Bureau of Rural Sciences, Canberra, p. 8.

Neilsen, W.A., Gerrand, A.M., 1999. Growth and branching habit of Eucalyptus nitens at different spacing and the effect on final crop selection. For. Ecol. Manage. 123, 217-229.

Neilsen, W.A., Pinkard, E.A., 2000. Developing silvicultural regimes for sawlog and veneer production from temperate eucalypt plantations in Tasmania. In: The Future of Eucalypts for Wood Products, IUFRO Conference Proceedings. Forest Industries Association, Hobart, pp. 335-342.

Niemistö, P., 1995. Influence of initial spacing and row-to-row distance on the growth and yield of silver birch (Betula pendula). Scand. J. For. Res. 10, 245-255.

Nikles, D.G., Lee, D.J., Robson, K.J., Pomroy, P.C., Walker, S.M., 2000. Progress on species selection trials and genetic improvement of hardwoods for commercial plantings in Queensland. In: Snell, A., Vize, S. (Eds.),
Opportunities for the New Millennium, Conference Proceedings. Australian Forest Growers, Cairns, pp. 23-31.

NRM, 2007. Natural Resource Management. Data available online at http:// www.nrm.qld.gov.au/silo/datadrill (accessed January 15, 2007).

Opie, J.E., Curtin, R.A., Incoll, W.D., 1984. Stand management. In: Hillis, W.E., Brown, A.G. (Eds.), Eucalypts for Wood Production. CSIRO, Melbourne, pp. 179-200.

Otegbeye, G.O., Samarawira, I., 1992. Genetics of growth and quality characteristics of Eucalyptus camaldulensis Dehnh. Silvae Genet. 41, 249-252.

Pietilä, J., 1989. Factors affecting the healing-over of pruned Scots pine knots. Silva Fennica 23, 125-158.

Pinkard, E.A., Beadle, C.L., 1998. Effects of green pruning on growth and stem shape of Eucalyptus nitens (Deane and Maiden) Maiden. New Forest. 15, 107-126.

Pinkard, E.A., Neilsen, W.A., 2003. Crown and stand characteristics of Eucalyptus nitens in response to initial spacing: implications for thinning. For. Ecol. Manage. 172, 215-227.

Plumptre, R.A., 1979. Pruning of fast growing pines for wood uniformity: can you have your cake and eat it? Commun. For. Rev. 58, 181-189.

Rapraeger, E.F., 1939. Development of branches and knots in Western White Pine. J. For. 37, 239-245.

Schönau, A.P.G., 1974. The effect of planting espacement and pruning on growth, yield and timber density of Eucalyptus grandis. S. Afr. For. J. 88, $16-23$.

Schönau, A.P.G., 1984. Silvicultural considerations for high productivity Eucalyptus grandis. For. Ecol. Manage. 9, 295-314.

Schönau, A.P.G., Coetzee, J., 1989. Initial spacing, stand density and thinning in eucalypt plantations. For. Ecol. Manage. 29, 245-266.

Shepherd, K.R., 1986. Plantation silviculture. Martinus Nijhoff Publishers, Dordrecht, p. 322.

Shepherd, K.R., McKinnell, F.H., Neilsen, W.A., Squire, R.O., 1990. Silvicultural regimes for Australian plantations. In: Dargavel, J., Semple, N. (Eds.), Prospects for Australian Forest Plantations. Centre for Resource and Environmental Studies, Canberra, pp. 241-255.

Smith, D.M., Larson, B.C., Kelty, M.J., Ashton, P.M.S., 1997. The Practice of Silviculture: Applied Forest Ecology. John Wiley and Sons Inc., New York, p. 537.

Smith, R.G.B., Dingle, J., Kearney, D., Montagu, K., 2006. Branch occlusion after pruning in four contrasting sub-tropical eucalypt species. J. Trop. For. Sci. 18, 117-123.

Soares, P., Tomé, M., 2001. A tree crown ratio prediction equation for eucalypt plantations. Annu. For. Sci. 58, 193-202.

Stanton, R., 1992. Eucalyptus plantations in New South Wales. Research Paper No. 15. Forestry Commission of New South Wales, Sydney, September 1992, p. 29.

van Laar, A., Bredenkamp, B., 1979. The effect of initial spacing on some growth parameters of Eucalyptus grandis. S. Afr. For. J. 111, 58-63.

Wardle, P.A., 1967. Spacing in plantations-a management investigation. Forestry 40, 47-69.

Ware, L.M., Stahelin, R., 1948. Growth of southern pine plantations at various spacings. J. For. 46, 267-274.

Washusen, R., Waugh, G., Hudson, I., Vinden, P., 2000. Appearance product potential of plantation hardwoods from medium rainfall areas of the southern Murray-Darling Basin. Green product recovery. Aust. For. 63, 66-71.

Waugh, G., 1996. Properties of plantation-grown eucalypts. Farm forestry \& plantations: investing in future wood supply.In: Conference Proceedings, Australian Forest Growers, Mount Gambier, South Australia, September 912. Commonwealth Department of Primary Industries and Energy, Canberra, pp. 83-93.

Yang, J.L., Waugh, G., 1996. Potential of plantation-grown eucalypts for structural sawn products. II. Eucalyptus nitens (Dean \& Maiden), Maiden and E. regnans F. Muell. Aust. For. 59, 99-107. 